\title{
In Memoriam: John Clayton Kingston (1949-2004)
}

\author{
Eugene F. Stoermer ${ }^{1, *}$ and John P. Smol ${ }^{2}$ \\ ${ }^{1}$ School of Natural Resources and Environment, University of Michigan, Ann Arbor, Michigan 48109-1115, \\ USA; ${ }^{2}$ Department of Biology, Paleoecological Environmental Assessment and Research Laboratory \\ (PEARL), Queen's University, Kingston, Ontario K7L 3N6, Canada; *Author for correspondence (e-mail: \\ stoermer@umich.edu)
}

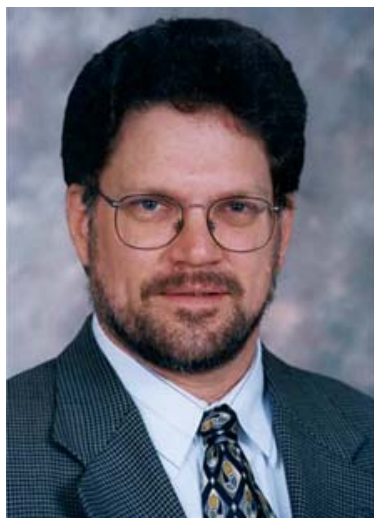

John Kingston was born September 261949 in Austin, Minnesota and died from the effects of a brain tumor in Ely, Minnesota on June 92004. With John's premature passing, our field lost an exceptional intellect, and a truly unique personality.

John undertook his secondary education in the public schools of Austin, Minnesota and obtained his BS in Botany from Iowa State University in 1970, his MS from the University of Delaware in 1975, and his $\mathrm{PhD}$ from Bowling Green State University in 1980 .

John's first and abiding interest was the natural history, particularly the taxonomy, of diatoms. His interest in natural history was sparked by his boyhood exposure to nature, and he remained an avid outdoorsman for his entire life. His interest in diatoms was developed primarily by interactions with Dr John D. Dodd, an inspiration to many American diatomists. As an undergraduate, John particularly enjoyed the opportunities and atmosphere of Iowa Lakeside Laboratory. He took the Laboratory's diatom class, taught by Dr C.W. Reimer, in 1969, and then returned as an honors research student in 1970, and continued to return as a research investigator and guest scientist on numerous occasions. The degree to which the research opportunities and collegial interactions provided by Lakeside Lab affected John's career is reflected by the fact that he requested his ashes be returned there.

After graduation, John pursued his MS studies under Dr Ruth Patrick, one of the major figures in the study of the North American diatom flora. Although his MS was granted by the University of Delaware, he had substantial intellectual support from Curators at the Academy of Natural Sciences, Philadelphia. Besides Dr Patrick, Dr Charles W. Reimer was especially instrumental in shaping John's career aspirations. Following a brief stint in a technical position in Gene Stoermer's lab at the University of Michigan, he undertook his doctoral research under the direction of Rex Lowe, completing his doctorate in 1980. His doctoral dissertation, published in Ecology in 1983, provided unique insights into structuring of diatom communities in Lake Michigan, and large oligotrophic lakes in general.

During his graduate studies he met, or as he was wont to say, re-met, Sarah Rayman, the 'little' sister of a close secondary school friend, who was to become a constant and stabilizing influence in his life and career. They married in 1976 and continued to share their love for nature, a liberal view of life, and each other, to the end of John's life. The union produced two sons, O`Neil and Hudson, who, together with Sarah, survive. 
John began concentrated work in paleolimnology when he undertook post-doctoral research at the University of Minnesota's Limnological Research Center (LRC), under the direction of Dr Herb Wright. This was a natural connection. Wright recognized the great potential power of diatom analyses in reconstructing Quaternary histories before the topic was popular in North America and frequently sponsored foreign diatom investigators, such as Maj Brit Florin and Elizabeth Haworth, at the LRC.

The LRC of that era provided John with both the mode for expanding his research interests and contact with professional colleagues who helped shape and forward his career. Notable among the Minnesota group were Dr Dan Engstrom and Dr Sheri Fritz, who published with John during his tenure at LRC and in the years following. Work at LRC also provided John with contact with many foreign colleagues whose perspectives he greatly valued and whose company he greatly enjoyed. Throughout his career John was an astonishingly active correspondent who was one of the first diatomists and paleolimnologists to appreciate the power of the internet. Those interested in diatoms and paleolimnology, in any part of the world and in any research capacity, but particularly students, benefited from his extensive experience, knowledge of the literature, and keen insights as well as his willingness to communicate.

John's tenure at LRC was also particularly fortunate in terms of timing. Like many diatomists of his and previous generations he was forced, by lack of academic positions in his specialty, to approach his main interest more or less obliquely, through more easily sponsored research in various branches of ecology. By the end of John's post-doctoral program, the problems of lake acidification and the potential for diatom-based reconstructions to provide insights into past acidification trajectories were becoming evident. John's first professional position in paleolimnology was leadership of the group at the University of Minnesota at Duluth engaged in the large, multi-investigator and multiinstitutional study termed Paleoecological Investigations of Recent Lake Acidification (PIRLA). The PIRLA project influenced the career of many North American paleoecologists. In John's case, it put him in contact with most of the active investigators in the world, including the growing paleolimnology group at Queen's University in

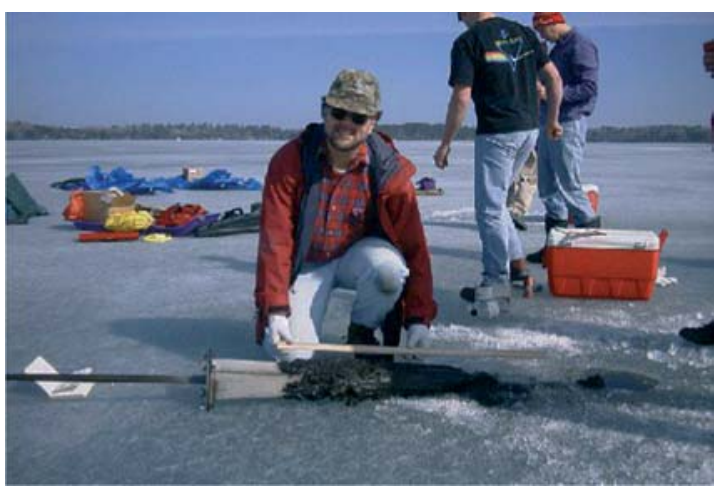

Kingston, Ontario. At the conclusion of the PIRLA project John moved to Queen's as a research scientist at PEARL where he was instrumental in bringing the tools of diatom-based ecological reconstructions, as they are currently understood, to a number of topics. In retrospect, this was probably the most productive period of his career in terms of quantity and novelty of publications.

Faced with the vagaries of funding in an untenured position, John eventually opted for a more stable, if perhaps less intellectually stimulating position, as an environmental manager with the Canadian provincial government of Newfoundland. Although he found the ecological problems of the region fascinating, and genuinely fell in love with the local culture and music, deteriorating economic conditions and the depression-spawned 'one job per family' philosophy that limited possibilities for Sarah, eventually drove him to seek other opportunities. In truth, John was not ideally suited for the inevitable constraints of a governmental position. He possessed the type of inquiring mind that always found more problems than answers. He was also more attendant to academic rigor than to the rigors of report production, although he certainly had a talent for the latter. 'Good enough for government work' was simply not part of John's vocabulary.

Unfortunately, the next turn in John's career path tended to crystallize the conflict between his ideal world and the realities of the day. He accepted a position with the United States Geological Survey National Water Quality Assessment Program (NAWQA). In theory this should have been an ideal position for John, and John should have been an ideal person for the position. The NAWQA program samples many largely unexplored habitats in poorly known, at least so far as 
the diatom flora is concerned, parts of North America. Because of this there was a large need for careful taxonomic assessments and quality control. Although John and the co-workers he enlisted to the project managed to produce some of the required background, he became increasingly conflicted between his intellectual aspirations and the rigid requirements of the federal bureaucracy.

The potential solution arrived in the form of his final position at the Center For Water and the Environment, Natural Resources Research Institute, University of Minnesota, Duluth. This position allowed John more latitude to pursue research and especially allowed him to investigate problems of his favorite research topics, sub-boreal lakes and the Laurentian Great Lakes of North America. Cruelly, these dreams were cut short by his terminal disease.

This brief recapitulation of John's career and the list of his publications that follows does not begin to really capture his scientific impact. Personally, he was a genuine 'frontier liberal academic', a type more commonly encountered in previous generations. Social and academic graces were not his main concerns, but he was generous and honest almost to a fault. An extremely empathetic person, his first individually published paper was a memorial to a brilliant young investigator whose career was tragically cut short. $\mathrm{He}$ was an editor's or a project officer's dream as a reviewer, knowledgeable and demanding, but always constructive. He was patient and thorough with students and beginners, either in person or through correspondence, and perhaps his most lasting legacy will be found in those he helped as beginners to the field of diatom taxonomy, as well as paleolimnology.

John's incisive intellect and dry humor will be sorely missed by those fortunate enough to know him well, and by the rest of our research community denied this opportunity by fate.

\section{John Kingston's Publications}

Ector L., Kingston J.C., Charles D.F., Denys L., Douglas M.S.V., Manoylov K., Michelutti N., Rimet F., Smol J.P., Stevenson R.J., and Winter J. 2004. Workshop report. Freshwater diatoms and their role as ecological indicators. In:
Poulin M. (ed.), Proceedings of the 17th International Diatom Symposium 2002, Otttawa, Canada. Biopress Limited, Bristol, pp. 469-480. Danz N.P., Regal, R.R., Niemi G.J., Brady V., Hollenhorst T., Johnson L.B., Host G.E., Hanowski J.M. Johnston C.A., Brown T., Kingston J.C. and Kelly J.R. 2004. Environmentally stratified sampling design for the development of Great Lakes environmental indicators. J. Environ. Monitor. Assess. In press.

Kingston J.C., Engstrom D.R., Norton A.R., Peterson M.R., Griese N.A., Stoermer E.F. and Andresen N.A. 2004. Paleolimnological inference of nutrient loading in a eutrophic lake in north central Minnesota (USA) and periodic occurrence of abnormal Stephanodiscus niagarae. In: Poulin M. (ed.), Proc. 17th Internat. Diatom Symp. Biopress, Bristol, pp. 187-202.

Kingston J.C. 2003. Araphid and monoraphid diatoms (Chapter 16). In: Wehr J. and Sheath R. (eds), Freshwater Algae of North America. Academic Press, San Diego, pp. 595-636.

Kingston J.C., Sherwood A.R. and Bengtsson R. 2001. Morphology and taxonomy of several Fragilariforma taxa from Fennoscandia and North America. In: Economou-Amilli E. (ed.), Proc. 16th Internat. Diatom Symp. Amvrosiou Press, Athens, pp. 73-83.

Kingston J.C. 2000. New combinations in the freshwater Fragilariaceae and Achnanthidiaceae. Diatom Res. 15: 409-411.

Kociolek J.P. and Kingston J.C. 1999. Taxonomy, ultrastructure, and distribution of some gomphonemoid diatoms (Bacillariophyceae: Gomphonemataceae) from rivers in the US. Can. J. Bot. 77: 686-705.

Kociolek J.P., Spaulding S.A. and Kingston J.C. 1998. Valve morphology and systematic position of Navicula walkeri (Bacillariophyceae), a diatom endemic to Oregon and California. Nova Hedwigia 67: 235-245.

Agbeti M.D., Kingston J.C., Smol J.P. and Watters C. 1997. Comparison of phytoplankton succession in two lakes of different mixing regimes. Archiv. Hydrobiol. 140: 37-69.

Kingston J.C. 1997. Information on algal phylogenetic order. http://wwwnwql.cr.usgs.gov/ USGS/algae/algae.phylo.info.html

Canadian Council of Ministers of the Environment. 1994. Proceedings of the Workshop on 
Developing Ecosystem Health Indicators, 17 October 1993, Québec City, Environment Canada, Evaluation and Interpretation Branch. Ottawa, Ontario, 51 pp.

Department of Environment \& Environment Canada. 1994. 1991-1992 Annual Report, Canada-Newfoundland Water Quality Monitoring Agreement. Water Resources Management Division, St. John's, Newfoundland, $32 \mathrm{pp}$.

Kingston J.C. 1994. Diatom research in Labrador: one component of freshwater biodiversity. In: Proc. 4th Arctic-Antarctic Diatom Symposium (Workshop). Canadian Museum of Nature, Ottawa, Ontario. Can. Tech. Rep. Fish. Aquat. Sci. 1957: 53-56.

Kingston J.C. 1994. Whole-basin water quality of the Salmonier River, Avalon Peninsula, Newfoundland, 1986-1991. In: Liverman D. and Hall J. (eds), TERRAMON Report Series No. 3. Centre for Earth Resources Research. St. John's, Newfoundland, pp. 44-51.

Water Resources Management Division. 1994. Surface and groundwater quality of the Nut Brook sub-basin, Kelligrews River. Department of Environment, St. John's, Newfoundland, $40 \mathrm{pp}$.

Davenport P.H., Finch C., McConnell J.W., Kingston J.C. and Collins G. 1993. Seasonal variation in surface-water geochemistry. Report of Activities 1993, Department of Mines and Energy, Government of Newfoundland and Labrador. St. John's, Newfoundland, pp. 3-5.

Dixit S.S., Cumming B.F., Birks H.J.B., Smol J.P., Kingston J.C., Uutala A.J., Charles D.F. and Camburn K.E. 1993. Diatom assemblages from Adirondack Lakes (New York, USA) and the development of inference models for retrospective environmental assessment. J. Paleolim. 8: 27-47.

Fritz S.C., Kingston J.C. and Engstrom D.R. 1993. Quantitative trophic reconstruction from sedimentary diatom assemblages: a cautionary tale. Freshwater Biol. 30: 1-23.

Hamilton P.B., Poulin M. and Kingston J.C. 1993. A taxonomic and morphological study of an acidobiontic diatom, Neidium holstii (Cleve) Krammer from North America and Greenland. Nova Hedwigia Beih. 106: 109-119.

Kingston J.C. 1993. Water quality monitoring in Newfoundland and Labrador. In: Proc.
TERRAMON/Geological Association of Canada Conference 'The Scientific Challenge of our Changing Environment.' Canadian Global Change Program, Incidental Report Series No. IR93-2. Royal Society of Canada, Ottawa, pp. 73-74.

Kingston J.C. 1993. Monitoring activities of the water resources management division. In: Proc. TERRAMON/Geological Association of Canada Conference 'The Scientific Challenge of our Changing Environment,' Canadian Global Change Program, Incidental Report Series No. IR93-2. Royal Society of Canada, Ottawa, p. 75.

Cumming B.F., Smol J.P., Kingston J.C., Charles D.F., Birks H.J.B., Camburn K.E., Dixit S.S., Uutala A.J. and Selle A.R. 1992. How much acidification has occurred in Adirondack region (New York, USA) lakes since pre-industrial times? Can. J. Fish. Aquat. Sci. 49: 128-141.

Kingston J.C., Cumming B.F., Uutala A.J., Smol J.P., Camburn K.E., Charles D.F., Dixit S.S. and Kreis R.G. Jr. 1992. Biological quality control and quality assurance: a case study in paleolimnological Biomonitoring. In: McKenzie D.H., Hyatt D.E. and McDonald V.J. (eds), Ecological Indicators, Vol. 2. Elsevier Applied Science, London, pp. 1542-1543.

Dixit S.S., Smol J.P., Kingston J.C. and Charles D.F. 1992. Diatoms: powerful indicators of environmental change. Environ. Sci. Technol. 26: $22-33$.

Dixit S.S., Cumming B.F., Smol J.P. and Kingston J.C. 1992. Monitoring environmental changes in lakes using algal microfossils. In: McKenzie D.H., Hyatt D.E. and McDonald V.J. (eds), Ecological Indicators, Vol. 2. Elsevier Applied Science, London, pp. 1135-1155.

Kingston J.C., Cumming B.F., Uutala A.J., Smol J.P., Camburn K.E., Charles D.F., Kingston J.C., Birks H.J.B., Uutala A.J., Cumming B.F. and Smol J.P. 1992. Assessing trends in fishery resources and lake water aluminium from paleolimnological analyses of siliceous algae. Can. J. Fish. Aquat. Sci. 49: 116-127.

Sullivan T.J., Turner R.S., Charles D.F., Cumming B.F., Smol J.P., Schofield C.L., Driscoll C.T., Cosby B.J., Birks H.J.B., Uutala A.J., Kingston J.C., Dixit S.S., Bernert J.A., Ryan P.F. and Marmorek D.R. 1992. Use of historical assessment for evaluation of process-based 
model projections of future environmental change: lake acidification in the Adirondack Mountains, New York, USA. Environ. Poll. 77: 253-262.

Kingston J.C. 1991. Some brief critical comments on Round et al. (1990), 'Concepts in diatom systematics,' In: Poulin M. (ed.), Proc. 3rd Polar Diatom Colloquium, Canadian Museum of Nature, Ottawa, Ontario, Canada, August 510, 1990. Can. Tech. Rep. Fish. Aquat. Sci. 1781: 1-13.

Kingston J.C. 1991. Gradient analysis: recent developments in diatom ecological research. In: Poulin M. (ed.), Proc. 3rd Polar Diatom Colloquium, Canadian Museum of Nature, Ottawa, Ontario, Canada, August 5-10, 1990: Can. Tech. Rep. Fish. Aquat. Sci. 1781: 15.

Stevenson A.C., Juggins S., Birks H.J.B., Anderson D.S., Anderson N.J., Battarbee R.W., Berge F., Davis R.B., Flower R.J., Haworth E.Y., Jones V.J., Kingston J.C., Kreiser A.M., Line J.M., Munro M.A.R. and Renberg I. 1991. The Surface Water Acidification Project Palaeolimnology Programme. Modern Diatom/Lake-Water Chemistry Data-Set. ENSIS Publishing, London, UK. 86 pp.

Cook R.B., Kreis R.G. Jr. Kingston J.C., Camburn K.E., Norton S.A., Mitchell M., Fry B. and Shane L.C. 1990. Paleolimnology of McNearney Lake: an acidic lake in northern Michigan. J. Paleolimnol. 3: 13-34.

Cumming B.F., Smol J.P., Dixit S.S., Kingston J.C. and Uutala A.J. 1990. Close interval paleolimnology. In: Sullivan T.J. (ed.), Historical Changes in Surface Water Acid-base Chemistry in Response to Acidic Deposition. Report 11, NAPAP State of Science and Technology. National Acid Precipitation Assessment Program, Washington, DC, pp.129-135.

Cumming B.F., Smol J.P., Kingston J.C., Dixit S.S., Uutala A.J., and Charles D.F. 1990. Paleolimnological variability. Appendix A. In: Sullivan T.J. (ed.), Historical Changes in Surface Water Acid-base Chemistry in Response to Acidic Deposition, Report 11, NAPAP State of Science and Technology. National Acid Precipitation Assessment Program, Washington, DC, 6 pp.

Kingston J.C., Camburn K.E., Kreis R.G. Jr. and Uutala A.J. 1990. Diatom counts of Northern Great Lakes region lake surface sediment sam- ples, PIRLA Report Series. Queen's University, Kingston, Ontario, Report Number 16.

Kingston J.C., Camburn K.E., Kreis R.G. Jr. and Uutala A.J. 1990. Diatom counts of Northern Great Lakes region lake sediment core intervals, PIRLA Unpublished Report Series. Queen's University, Kingston, Ontario, Report Number 17.

Kingston J.C. and Birks H.J.B. 1990. Dissolved organic carbon reconstructions from diatom assemblages in PIRLA project lakes, North America. Philos. Trans. R. Soc. London, Ser. B. 327: 279-288 + microfiche.

Kingston J.C., Kreis R.G. Jr. Cook R.B., Camburn K.E., Norton S.A., Sweets P.R., Binford M.W., Mitchell M.J., Schindler S.C., Shane L. and King G. 1990. Paleoecological investigation of recent lake acidification in the Northern Great Lakes States. J. Paleolimnol. 4: 153-201.

Kingston J.C. 1990. Recent paleolimnological advancements. In: Sullivan T.J. (ed.), Historical Changes in Surface Water Acid-base Chemistry in Response to Acidic Deposition. Report 11, NAPAP State of Science and Technology: National Acid Precipitation Assessment Program, Washington, DC, pp. 67-68.

Kingston J.C., Thomas D.R. and Bernert J.A. 1990. Error estimation. In: Sullivan T.J. (ed.), Historical Changes in Surface Water Acid-base Chemistry in Response to Acidic Deposition. Report 11, NAPAP State of Science and Technology. National Acid Precipitation Assessment Program, Washington, DC, pp. 72-73.

Munro M.A.R., Kreiser A.M., Battarbee R.W., Juggins S., Stevenson A.C., Anderson D.S., Anderson N.J., Berge F., Birks H.J.B., Davis R.B., Flower R.J., Fritz S.C., Haworth E.Y., Jones V.J., Kingston J.C. and Renberg I. 1990. Diatom quality control and data handling. Philos. Trans. R. Soc. London, Ser. B. 327: 257-261.

Pillsbury R.W. and Kingston J.C. 1990. The pHindependent effects of aluminium on cultures of phytoplankton from an acidic Wisconsin lake. Hydrobiologia 194: 225-233.

Smol J.P., Cumming B.F. and Kingston J.C. 1990. QA in paleolimnology. In: Biology in the New Regulatory Framework for Aquatic Protection - QA/QC Procedures. Report prepared for: Environment Canada Conservation and Pro- 
tection Inland Waters Directorate: Brampton, Ontario. Beak Consultants Limited.

Cumming B.F., Smol J.P., Uutala A.J. and Kingston J.C. 1989. Adirondack lake morphometric maps and sediment coring field notes, 1987-1989, PIRLA II. Report Number 2. Queen's University, Kingston, Ontario, 157 pp.

Kingston J.C., Camburn K.E., Kreis R.G. Jr. and Cook R.B. 1989. Diatom distribution and association in softwater lakes of Minnesota, Wisconsin, and Michigan, Section 9. In: Charles D.F. and Whitehead D.R. (eds), Paleoecological Investigation of Recent Lake Acidification: 1983-1985. Electric Power Research Institute, Palo Alto, CA.

Kreis R.G. Jr. Kingston J.C., Camburn K.E. and Cook R.B. 1989. Diatom pH relationships in the Northern Great Lakes region for predicting past lake acidity. Section 10. In: Charles D.F. and Whitehead D.R. (eds), Paleoecological Investigation of Recent Lake Acidification: 1983-1985. Electric Power Research Institute, Palo Alto, CA.

Smol J.P., Cumming B.F., Uutala A.J., Kingston J.C. and Dixit S.S. 1989. Coring equipment and procedures used for lakes in the Adirondacks. PIRLA II, Report Number 1. Queen's University, Kingston, Ontario.

Cook R.B., Kelley C.A., Kingston J.C. and Kreis R.G. Jr. 1987. Chemical limnology of soft water lakes in the Upper Midwest. Biogeochemistry 4: 97-117.

Kingston J.C. 1988. Book review of Dodd J.J. 1987. The Illustrated Flora of Illinois, Diatoms, Southern Illinois University Press. Am. Sci. 76: 515-516.

CrismanT.L., Davis R.B., Ford J., Fry B.D., Hites R.A., Kahl J.S., Kingston J.C., Kreis R.G. Jr. Mitchell M.J., Norton S.A., Roll L., Smol J.P., Sweets P.R., Uutala A., White J.R., Whiting M. and Wise R. 1987. The PIRLA Project (Paleoecological Investigation of Recent Lake Acidification): Preliminary results for the Adirondacks, New England, N. Great Lakes States, and N. Florida. Water, Air, Soil Pollute. 30: $355-365$.

Camburn K.E. and Kingston J.C. 1986. The genus Melosira from softwater lakes with special reference to northern Michigan, Wisconsin, and Minnesota. In: Smol J.P., Battarbee R.W., Davis R.B. and Meriläinen J. (eds), Diatoms and Lake Acidity, Developments in Hydrobiology. Dr. W. Junk, Dordrecht, The Netherlands, pp. 17-34.

Kingston J.C. 1986. Diatom analysis basic protocol (Chapter 6). In: Charles D.F. and Whitehead D.R. (eds), Paleoecological Reconstruction of Recent Lake Acidification (PIRLA), Methods and Project Description. Electric Power Research Institute, Palo Alto, CA.

Battarbee R.W., Flower R.J., Jones V., van Dam H., Arzet K., Luikkonen M., Kingston J., Camburn K., Anderson D., Round F. and Simola H. 1986. Diatoms and acid lakes: report on a workshop. In: Ricard M. (ed.), Proc. 8th Internat. Diatom Symp. Paris, 1984. Otto Koeltz, Koenigstein, Germany, pp. 747-755.

Engstrom D.R., Swain E.B. and Kingston J.C. 1985. A paleolimnological record of human disturbance from Harvey's Lake, Vermont: geochemistry, pigments and diatoms. Freshwater Biol. 15: 261-288.

Camburn K.E., Kingston J.C. and Charles D.F. (eds), 1984-1986. PIRLA Diatom Iconograph; 53 photographic plates, 1059 Figures, Figure legends, and Index. PIRLA Unpublished Report Series, Report Number 3. Indiana University, Bloomington, Indiana.

Kingston J.C. 1984. Paleolimnology of a lake and adjacent fen in southeast Labrador: evidence from diatom assemblages. In: Mann D.G. (ed.), Proc. 7th Internat. Diatom Symp. Philadelphia, PA, 1982. Otto Koeltz, Koenigstein, Germany, pp. 443-453.

Engstrom D.R., Swain E.B. and Kingston J.C. 1983. A paleolimnological record of human disturbance from Harvey's Lake, Vermont: geochemistry, oscillaxanthin, and diatoms. Report to Vermont Department of Water Resource and Environmental Engineering, 66 pp.

Kingston J.C., Lowe R.L., Stoermer E.F. and Ladewski T.B. 1983. Spatial and temporal distribution of benthic diatoms in northern Lake Michigan. Ecology 64: 1566-1580.

Kingston J.C. 1982. Association and distribution of common diatoms in surface samples from northern Minnesota Peatlands. Nova Hedwigia, Beih. 73: 333-346.

Lowe R.L., Rosen B.H. and Kingston J.C. 1982. A comparison of epiphytes on Bangia atropurpurea (Rhodophyta) and Cladophora glom- 
erata (Chlorophyta) from northern Lake Michigan. J. Great Lakes Res. 8: 164-168.

Rosen B.H., Kingston J.C. and Lowe R.L. 1981. Observations of differential epiphytism on Cladophora glomerata and Bangia atropurpurea from Grand Traverse Bay, Lake Michigan. Micron 12: 219-220.

Kingston J.C., Lowe R.L. and Stoermer E.F. 1980. The frustular morphology of Amphora thumensis (Mayer) A. Cl. from northern Lake Michigan and consideration of its systematic position. T. Am. Microsc. Soc. 99: 276-283.

Kingston J.C., Lowe R.L. and Stoermer E.F. 1979. Attached winter floral assemblages on sand from Grand Traverse Bay, Lake Michigan. Micron 10: 203-204.

Stoermer E.F., Kingston J.C. and Sicko-Goad L. 1979. The morphology and taxonomic rela- tionships of Stephanodiscus binderanus var. oestrupii (A.Cl.) A.Cl. In: Simonsen R. (ed.), Proc. 5th Symp. on Living and Fossil Diatoms, Antwerp, Belgium. Nova Hedwigia, Beih. 64: 65-78.

Kingston J.C. 1978. Morphological variation of Cymbella delicatula and C. hustedtii from Northern Lake Michigan. T. Am. Microsc. Soc. 97: 311-319.

Kingston J.C. 1977. In Memoriam, William L. O'Neill, 1949-1974. Proc. Iowa Acad. Sci. 84: 128.

Stoermer E.F., Bowman M.M., Kingston J.C. and Schaedel A.L. 1975. Phytoplankton composition and abundance in Lake Ontario during the International Field Year for the Great Lakes. US Environmental Protection Agency, Corvallis, Oregon, 373 pp. 